\title{
Scrofuloderma: A Diagnosis to Bear in Mind in the Western World
}

\section{Escrofuloderma: Um Diagnóstico a Ponderar no Mundo Ocidental}

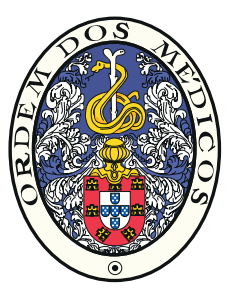

\author{
Mariana BATISTA $\triangle^{1}$, Barbara FERREIRA ${ }^{1}$, Gonçalo CRUZ $^{2}$, Américo FIGUEIREDO ${ }^{1}$ \\ Acta Med Port 2019 Apr;32(4):313-316 - https://doi.org/10.20344/amp.10329
}

\section{ABSTRACT}

The incidence of tuberculosis has been increasing worldwide. Contrarily, a recent decrease in Portugal has been reported. Cutaneous tuberculosis comprises a low percentage of all cases. We report a 70-year-old female with a 2-month-history of painful, nodular, suppurative lesions in the groin area, bilaterally. Previous history was remarkable for Human Immunodeficiency Virus infection and stage-IIIB cervical cancer. A skin biopsy, stained with periodic acid-Schiff and Fite's stain, polymerase chain reaction on purulent discharge and mycobacterial culture of the skin were performed, leading to the diagnosis of scrofuloderma. Tuberculostatic therapy was initiated and complete response was observed. This case depicts an uncommon variant of tuberculosis, highlighting the need for awareness of the cutaneous variants of tuberculosis that, although rare, can still present in the clinic today.

Keywords: Tuberculosis, Cutaneous

\section{RESUMO}

A incidência de tuberculose tem vindo a aumentar globalmente. Em Portugal, porém, esta incidência diminuiu na última década. A tuberculose cutânea representa uma pequena percentagem de todos os casos. Apresenta-se o caso de uma mulher de 70 anos com nódulos supurativos da região inguinal bilateralmente, dolorosos, evoluindo há 2 meses. Como antecedentes relevantes, apresentava infeção por vírus da imunodeficiência humana e carcinoma do colo do útero, estadio IIIB. Foram realizadas biópsia cutânea (coloração pelo ácido periódico de Shiff e coloração de Fite), pesquisa de micobactérias por polymerase chain reaction e estudo microbiológico por cultura, tendo sido estabelecido o diagnóstico de escrofuloderma. Iniciou terapêutiva tuberculostática com resposta favorável. Este artigo realça a importância do reconhecimento das formas cutâneas de tuberculose e a necessidade de manter um elevado índice de suspeição, sobretudo em pacientes imunodeprimidos.

Palavras-chave: Tuberculose Cutânea

\section{INTRODUCTION}

Over the last few years the incidence of tuberculosis has increased worldwide especially due to the increasing incidence of human immunodeficiency virus (HIV), ${ }^{1}$ which is ultimately responsible for most deaths among these patients. ${ }^{2,3}$ In Portugal, tuberculosis is still an important health care issue, although its incidence has been dropping - with an estimate of 16.5 new cases for 100000 inhabitants, with the majority of cases reported in the districts of Lisbon and Porto. ${ }^{4}$

Cutaneous involvement, although classical, remains an uncommon presentation of tuberculosis, comprising only $1.0 \%-1.5 \%$ of all extra-pulmonary manifestations. ${ }^{5-7} \mathrm{Cu}-$ taneous tuberculosis can be acquired exogenously (direct inoculation) or endogenously (contiguous infection or hematogenous dissemination) and can present a wide variety of clinical features. ${ }^{8}$

\section{CASE REPORT}

A 70-year-old caucasian female was seen with a 2-month-history of multiple, painful, erythematous, nodular, ulcerated and suppurative lesions in the groin area, bilaterally (Fig. 1).

Physical examination revealed palpable inguinal lymphadenopathy on the right side, without any other signifi- cant clinical findings. The patient was afebrile and denied night sweats or other systemic symptoms, and had not traveled abroad.

Previous history was remarkable for HIV seropositivity diagnosed 8 years before, under antiretroviral therapy with a current CD4 count of $242 / \mathrm{mm}^{3}$, negative viral load, and stage-IIIB cervical cancer treated with a chemo-radiotherapy scheme that had finished 2 years before.

Given the clinical picture described, the main diagnostic considerations included cutaneous metastases, mycobacterial and deep fungal infections. However, sexually transmitted diseases were also excluded, namely venereal lymphogranuloma, syphilis, gonorrhea, herpes virus and cytomegalovirus infections.

A skin biopsy showed a dermal tuberculoid granulomatous infiltrate with caseous necrosis, containing numerous multinucleated giant cells of the Langhans type accompanied by a rim of lymphocytes, plasma cells and occasional eosinophils (Fig. 2). Periodic acid-Schiff (PAS) and Fite's staining were negative. Polymerase chain reaction (PCR) performed on the exsudate revealed the presence of $M y$ cobacterium tuberculosis complex and routine bacterial culture was positive for Mycobacterium tuberculosis (MTB) (confirmed only 4 weeks later). IGRA (interferon gamma

\footnotetext{
1. Dermatology Department. Hospitais da Universidade de Coimbra. Centro Hospitalar e Universitário de Coimbra. Coimbra. Portugal.

2. Infectious Diseases Department. Hospitais da Universidade de Coimbra. Centro Hospitalar e Universitário de Coimbra. Coimbra. Portugal.

$\square$ Autor correspondente: Mariana Batista. sousabatistamariana@gmail.com

Recebido: 01 de fevereiro de 2018 - Aceite: 19 de junho de 2018 | Copyright @ Ordem dos Médicos 2019
} 


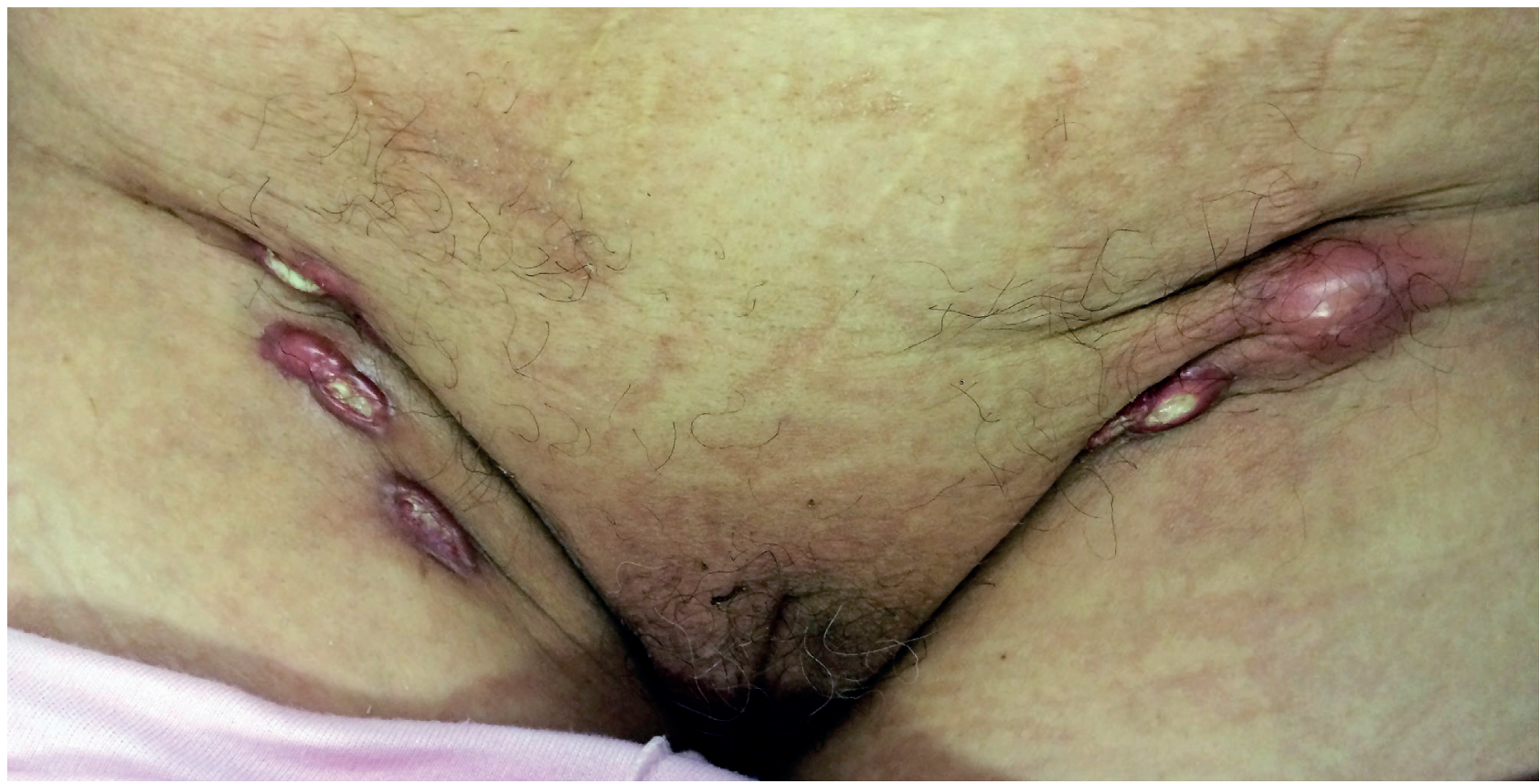

Figure 1 - Erythematous nodular lesions in the groin area with ulceration and suppurative content

release assay) test was also positive. A computed tomography scan showed contiguity between inguinal nodes and the overlying skin surface (Fig. 3 ). Chest x-ray did not reveal any abnormality.

The patient began treatment with a combination of pyrazinamide, isoniazid, ethambutol and rifampicin and her condition improved considerably in just two weeks of treatment. After 3 months of treatment only scarring was present (Fig. 4).

\section{DISCUSSION}

Scrofuloderma is a variant of cutaneous tuberculosis resulting from endogenous spread of the infection from a contiguous underlying focus, usually a lymph node or bone, with breakdown of the skin. ${ }^{9}$ The lesion starts as a subcutaneous, mobile nodule, which attaches to the overlying skin afterwards leading to abscess formation and purulent dis- charge. This clinical manifestation is classically described in young patients, ${ }^{10}$ and is more often seen in the axillae, neck, groin and chest. ${ }^{11,12}$ It's mainly associated with a state of lower immunity, with accompanying lower number of lymphocytes present in the granulomas and higher bacillary counts.

It's interesting to note that other variants of cutaneous tuberculosis - such as lupus vulgaris and tuberculosis verrucosa cutis, are associated with higher and intermediate immunocompetence states, respectively. ${ }^{13}$

Given the many clinical features of cutaneous tuberculosis and the fact that lesions resemble many other dermatological conditions, diagnosis can be difficult and requires correlation between clinical findings and diagnostic tests. In face of the delay in obtaining microbiological confirmation -4 weeks, PCR can be of value. It has high sensitivity and specificity, with results in less than $24-48$ hours. However,
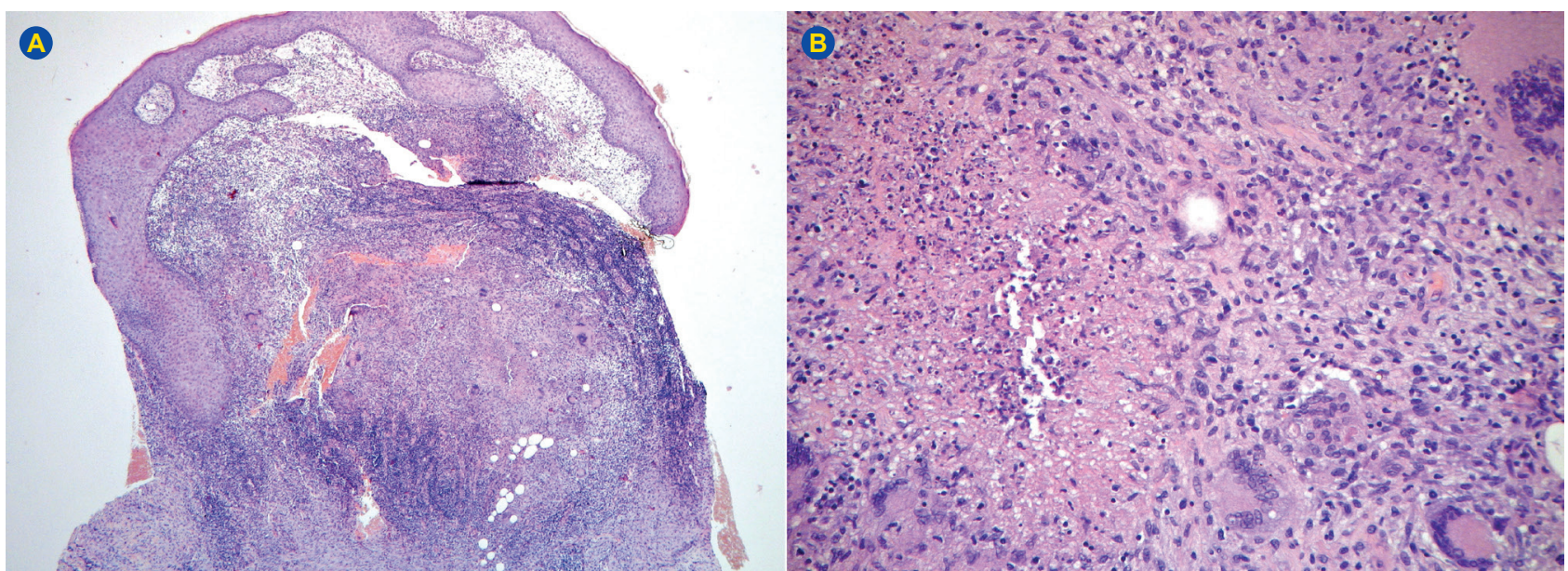

Figure 2 - (A) Diffuse epidermal hyperplasia with dermal granulomatous infiltrate of tuberculoid type. (B) Central necrosis with numerous multinucleated giant cells of the Langhans type. Haematoxylin and eosin, original magnification (A) x 40, (B) x 200 . 


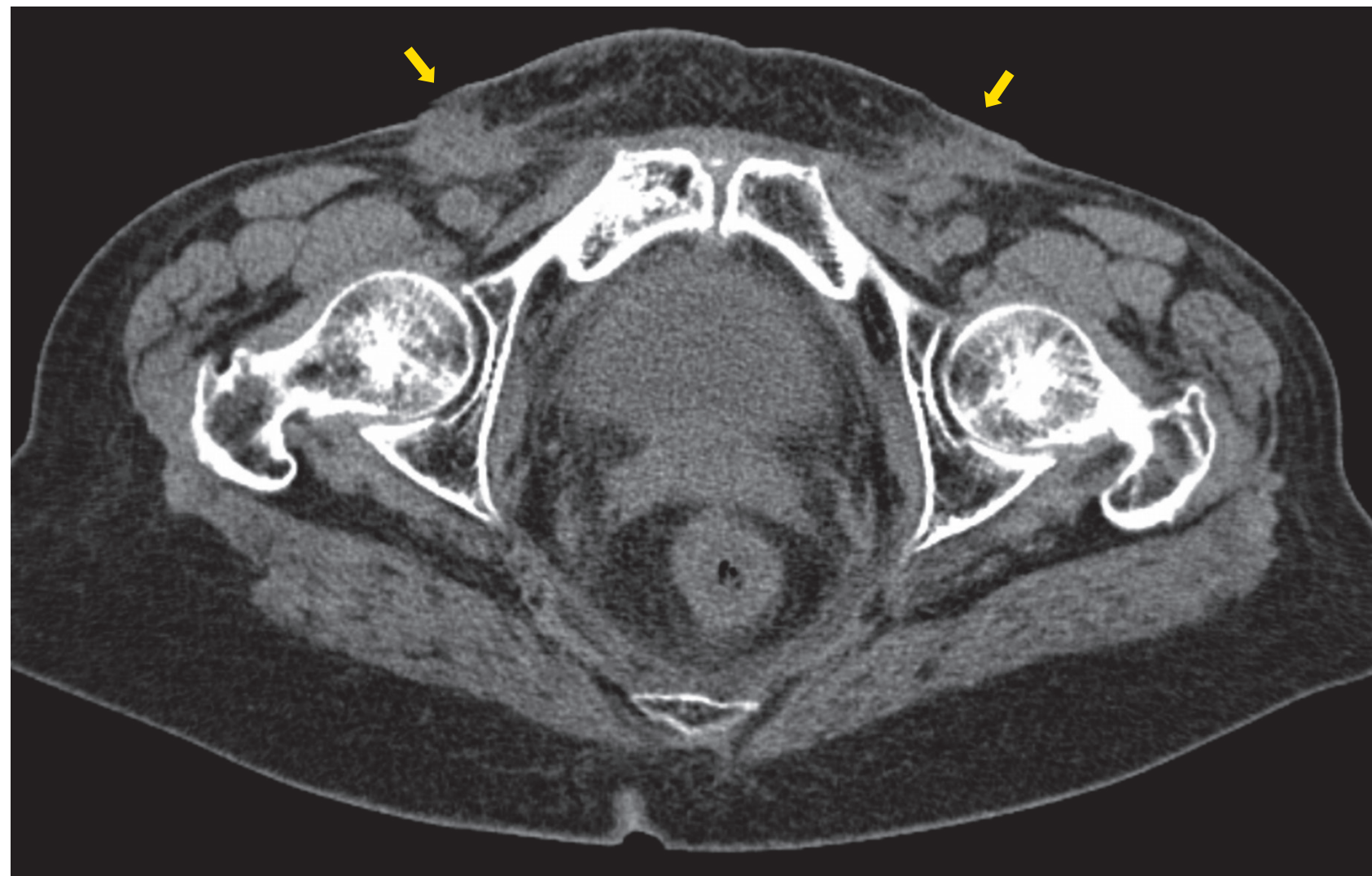

Figure 3 - Chest-abdomen-pelvis CT showing a contiguity between the nodular lesions and the skin (yellow arrows)

a positive result may not always correspond to an active infection and a negative result does not exclude it. Therefore, despite its utility, clinical correlation in mandatory ${ }^{14,15}$ In the setting of compatible clinical and histological features, even without a microbiological confirmation, tuberculostatic treatment should be started and, in these cases, the response to treatment can support the diagnosis.

In our patient, on clinical grounds alone, there was a possibility of cutaneous metastases from cervical cancer, given her medical history. However, the presence of typical tuberculoid granulomas in the skin combined with positive PCR for MBT, pointed to scrofuloderma, even in the absence of positive FITE and PAS stainings on histopathology. This was ultimately confirmed by isolation of MBT on routine bacterial culture (Löwestein-Jensen medium) 4

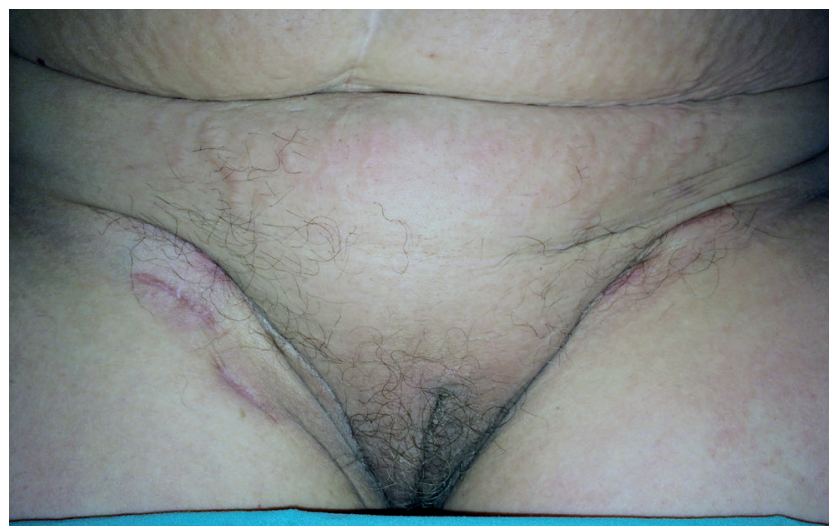

Figure 4 - Clinical appearance after three months of treatment weeks later. Sensitivity testing showed susceptibility to firstline tuberculostatics. The recommended treatment for cutaneous tuberculosis is the same as for systemic disease (two months of isoniazid, rifampin, ethambutol and pyrazinamide plus four months of isoniazid and rifampin). This scheme was carried out in our patient with good response.

This case is remarkable for several features: an uncommon presentation of tuberculosis - scrofuloderma - in a higher age group than average, maybe due to HIV-immunosuppression, with negative histochemical stain for mycobacteria in the cutaneous biopsy (unusual, although previously described), with a positive PCR for MBT and positive mycobacterial tissue culture.

Tuberculosis is still an important health issue and clinicians should be aware of atypical clinical presentations especially in the context of immunosuppression. Timely investigation is key and can prevent further complications.

\section{OBSERVATIONS}

This case was presented as a clinical case report in the Congress: Reunião da Primavera - Sociedade Portuguesa de Dermatologia e Venereologia, Lisbon, 2-3 June 2017.

\section{PROTECTION OF HUMANS AND ANIMALS}

The authors declare that the procedures were followed according to the regulations established by the Clinical Research and Ethics Committee and to the Helsinki Declaration of the World Medical Association. 


\section{DATA CONFIDENTIALITY}

The authors declare having followed the protocols in use at their working center regarding patients' data publication.

\section{PATIENT CONSENT}

Obtained.

\section{REFERENCES}

1. Corbett EL, Watt CJ, Walker N, Maher D, Williams BG, Raviglione MC et al. The growing burden of tuberculosis: global trends and interactions with the HIV epidemic. Arch Intern Med. 2003;163:1009-21.

2. Koenig SP, Riviere C, Leger P, Joseph P, Severe P, Parker K, et al. High mortality among patients with AIDS who received a diagnosis of tuberculosis in the first 3 months of antiretroviral therapy. Clin Infect Dis. 2009;48:829-31.

3. Etard JF, Ndiaye I, Thierry-Mieg M, Guèye N, Guèye P, Lanièce I, et al. Mortality and causes of death in adults receiving highly active antiretroviral therapy in Senegal: a 7 - year cohort study. AIDS. 2006;20:1181-9.

4. Direção Geral da Saúde. Programa Nacional para a Infeção VIH, SIDA e Tuberculose 2017. [consulted 2017 Dec 16]. Available from: http:// www.dgs.pt/portal-da- estatistica-da- saude/diretorio-de- informacao/ diretorio-de- informacao/por-serie- 845551- pdf.aspx?v=11736b1473e6- 4b34-a8e8- d22502108547.

5. Zhang J, Fan YK, Wang P, Chen QQ, Wang G, Xu AE, et al. Cutaneous tuberculosis in China: a multicenter retrospective study of cases diagnosed between 1957 and 2013. J Eur Acad Dermatol Venereol. J Eur Acad Dermatol Venereol. 2018;32:632-8.

6. Kivanc-Altunay I, Baysal Z, Ekmekçi TR, Koslu A. Incidence of cutaneous tuberculosis in patients with organ tuberculosis. Int $\mathrm{J}$ Dermatol. 2003;42:197-200.

\section{CONFLICTS OF INTEREST}

All authors report no conflict of interest.

\section{FUNDING SOURCES}

This research received no specific grant from any funding agency in the public, commercial, or not-for-profit sectors.

7. van Zyl L, du Plessis J, Viljoen J. Cutaneous tuberculosis overview and current treatment regimens. Tuberculosis. 2015;95:629-38.

8. Beyt BE Jr, Ortbals DW, Santa Cruz DJ, Kobayashi GS, Eisen AZ, Medoff $\mathrm{G}$. Cutaneous mycobacteriosis: analysis of 34 cases with a new classification of the disease. Medicine. 1981;60:95-109.

9. Hill MK, Sanders CV. Cutaneous tuberculosis. Microbiol Spectr. 2017;5

10. Ilgazli A, Boyaci H, Basyigit I, Yildiz F. Extrapulmonary tuberculosis: clinical and epidemiologic spectrum of 636 cases. Med Res Arch. 2004;35:435-41.

11. Concha RM, Fich SF, Rabagliati BR, Pinto SC, Rubio LR, Navea DÓ, et al. Cutaneous tuberculosis: two cases and review. Rev Chilena Infectol. 2011;28:262-8.

12. Kim GW, Park HJ, Kim HS, Kim SH, Ko HC, Kim BS, et al. Delayed diagnosis of scrofuloderma misdiagnosed as a bacterial abscess. Ann Dermatol. 2012;24:70-3.

13. Ramos-e- Silva M, Castro MC. Mycobacterial infections. In: Bolognia JL, Schaffer JV, Cerroni L. Dermatology. Elsevier; 2018. p. 1296-318.

14. Hsiao PF, Tzen CY, Chen HC, Su HY. Polymerase chain reaction based detection of Mycobacterium tuberculosis in tissues showing granulomatous inflammation without demonstrable acid-fast bacilli. Int. J. Dermatol. 2003;42:281-6.

15. Bento J, Silva AS, Rodrigues F, Duarte R. Diagnostic tools in tuberculosis. Acta Med Port. 2011;24:145-54 